\title{
Electrochemical Behavior of Zn-Ni Alloys in Borate Buffer Solutions
}

\author{
Ayman M. Zaky, Fawzi H. Assaf, and Fatma El Zhraa A. H. Ali \\ Department of Chemistry, Faculty of Science, South Valley University, Qena 83523, Egypt \\ Correspondence should be addressed to Ayman M. Zaky, azaky1@yahoo.com
}

Received 23 March 2011; Accepted 18 May 2011

Academic Editors: M. Marcos and H. C. Shih

Copyright ( $) 2011$ Ayman M. Zaky et al. This is an open access article distributed under the Creative Commons Attribution License, which permits unrestricted use, distribution, and reproduction in any medium, provided the original work is properly cited.

\begin{abstract}
The Electrochemical behavior of Zn-Ni alloys was studied in borate solutions using cyclic voltammetry, potentiodynamic anodic polarization, and current transient techniques under the effect of alloy composition, stepwise increasing potential, scan rate, and electrolyte concentration. The voltammogram consists of two potential regions separated by the critical potential $E_{\text {crit }}$. The first potential region involves the selective dissolution of the less noble metal, zinc, and the appearance of two anodic peaks $A_{1}$ and $A_{2}$. Peak $A_{1}$ is due to the formation of $\mathrm{Zn}(\mathrm{OH})_{2}$ and $A_{2}$ to the formation of $\mathrm{ZnO}$ on the alloy surface. The second potential region relates to the simultaneous dissolution of nickel. This region was characterized by the appearance of three anodic peaks $A_{3}, A_{4}$, and $A_{5}$ prior to the oxygen evolution reaction. These peaks are assigned to the formation of $\mathrm{Ni}(\mathrm{OH})_{2}, \mathrm{NiOOH}$, and $\mathrm{Ni}_{2} \mathrm{O}_{3}$, respectively. The anodic voltammetric profiles of the alloys lies below those of the pure metals indicating decreased rates of dissolution of the two metals, zinc and nickel, from the alloys. On alloying with nickel, the rate of zinc dissolution was decreased which increases its protective life as sacrificial anode for automobile body against corrosion. X-ray diffraction analysis confirmed the existence of $\mathrm{Zn}(\mathrm{OH})_{2}, \mathrm{ZnO}, \mathrm{Ni}(\mathrm{OH})_{2}$, and $\mathrm{Ni}_{2} \mathrm{O}_{3}$ with preferred orientations (008), (101), (002), and (202) of the alloy surface polarized to noble potentials. Potentiostatic current/time transients showed that the formation of $\mathrm{Zn}(\mathrm{OH})_{2}, \mathrm{ZnO}, \mathrm{Ni}(\mathrm{OH})_{2}, \mathrm{NiOOH}$, and $\mathrm{Ni}_{2} \mathrm{O}_{3}$ layers involves a nucleation and growth mechanism under diffusion control.
\end{abstract}

\section{Introduction}

The anodic behavior of zinc in $\mathrm{Na}_{2} \mathrm{~B}_{4} \mathrm{O}_{7}$ solutions has been investigated by the galvanostatic polarization technique. The polarization curves are characterized by one distinct arrest corresponding to $\mathrm{Zn}(\mathrm{OH})_{2}$ or $\mathrm{ZnO}$, after which the potential increases linearly with time before reaching the oxygen evolution region [1]. It is generally accepted that $\mathrm{Zn}$ passivation begins with the precipitation of the zincate ion as $\mathrm{Zn}(\mathrm{OH})_{2}$ or $\mathrm{ZnO}$ [2-5]. Powers and Breiter [6] examined the surface of Zn optically during potentiodynamic oxidation in stationary $\mathrm{KOH}$ solution. They noted the existence of two different precipitates [2] suggested that the first one was $\mathrm{Zn}(\mathrm{OH})_{2}$ and the second $\mathrm{ZnO}$. The electrochemical behavior of zinc in $\mathrm{NaOH}$ solutions was investigated [7] by using potentiodynamic technique and complemented by $\mathrm{X}$-ray analysis. They found that $E / i$ curves exhibit active, passive, and transpassive regions prior to reaching the oxygen evolution potential. The active region displays two anodic peaks. The passivity is due to the formation of a compact $\mathrm{Zn}(\mathrm{OH})_{2}$ film on the anode surface. The transpassive region is assigned to the electroformation of $\mathrm{ZnO}$.

In spite of the earlier studies, there remains considerable disagreement in the literature on the interpretation of the nature and the mechanism of the anodic layers on nickel $[8,9]$ considered the presence of $\mathrm{Ni}(\mathrm{OH})_{2}$ in the film. The anodic oxidation of nickel electrode in alkaline solutions in the potential ranges related to the $\mathrm{Ni} / \mathrm{Ni}(\mathrm{OH})_{2}$, and $\mathrm{Ni} / \mathrm{NiOOH}$ redox reactions have been studied under galvanostatic and potentiodynamic conditions. However, there is a general agreement that when nickel is immersed in alkaline solutions, spontaneous dissolution of the metal occurs followed by the formation of $\mathrm{Ni}(\mathrm{OH})_{2}$ [10] film. Recently [11] confirmed that the film formed in the passive region is composed of $\mathrm{NiO}$ (inner) and $\mathrm{Ni}(\mathrm{OH})_{2}$ (outer) in borate solutions, $\mathrm{NiO}$ being the passivating species. At potentials above a critical value, the $\beta-\mathrm{Ni}(\mathrm{OH})_{2}$ film is converted to an $\mathrm{Ni}(\mathrm{III})$ oxide phase, identified by ellipsometry as 
$\beta$-NiOOH [12]. The conversion of $\beta-\mathrm{Ni}(\mathrm{OH})_{2}$ to $\beta-\mathrm{NiOOH}$ is a complex process.

The aim of this study was to investigate the effect of alloying zinc with nickel on increasing the life time of sacrificial anodic protection of zinc for automobile body against corrosion. The electrochemical behavior of $\mathrm{Zn}-\mathrm{Ni}$ alloy in $0.15 \mathrm{~N}$ of borate solution. The voltammetric profiles of pure $\mathrm{Zn}$ and pure nickel were included for comparison. The microstructure and composition of the passive film formed during the anodic sweep were characterized by X-ray diffraction analysis.

\section{Experimental}

Three zinc-nickel alloys (Table 1), pure zinc and pure nickel (99.99\% pure supplied by Merck), were used in studying the cyclic voltammetric behavior of zinc-nickel alloys in $0.15 \mathrm{~N}$ of borate buffer solution. The alloys were made in the Aluminum Company of Egypt by fusing appropriate amounts of the two components in a graphite crucible at a desired temperature. They were cooled and made into cylindrical rods with a cross-sectional area $0.126 \mathrm{~cm}^{2}$.

All of the electrodes were mounted in Teflon so that only the cross-sectional area of $0.126 \mathrm{~cm}^{2}$ was in contact with solution. Before each experiment, the working electrode was polished with successively finer grades of emery paper and then with alumina paste to obtain a mirror-like surface finish then degreased with ethyl alcohol and rinsed with doubly distilled water. Then, the electrodes were transferred to the solution where they were left at $-2000 \mathrm{mV}$ for $1 \mathrm{~min}$, to remove any oxide present, before running the experiments.

The solutions used were prepared from Analar grade chemicals. All experiments were performed using freshly prepared solutions and freshly polished electrodes. The electrolytic cell used was of $100 \mathrm{~cm}^{3}$ capacity and consisted of three separate compartments, which were used for the working, counter, and reference electrodes. the counter electrode was a rod of graphite while the reference electrode was a saturated calomel electrode (SCE). The cyclic voltammetric polarization was applied by means of EG\&G potentiostat/Galvanostat Model 273A using the 352 SoftCorr III software on a Pentium II computer. The morphology of the alloy surface in the potential range beyond the critical potential $E_{\text {crit }}$ was monitored by SEM using a Philips model XL-200 instrument operated at $15 \mathrm{keV}$. The composition of the corrosion products formed on the alloy during anodic polarization was investigated by XRD analysis using a Philips P. W. Model 1730.

\section{Results and Discussion}

The electrochemical behavior of Zn-Ni alloys was studied in $0.15 \mathrm{~N}$ boric acid and $0.15 \mathrm{~N}$ borax (borate buffer solution) using cyclic voltammetric technique, and the data are given in Figure 1. The voltammograms were recorded between the starting cathodic potential $E_{c}=-1600 \mathrm{mV}$ and switching potential $E_{a}=1300 \mathrm{mV}$ at scan rate of $50 \mathrm{mVs}^{-1}$. The cyclic voltammetric behavior of pure zinc and pure nickel were introduced for comparison. In Figure 1, curve
TABLE 1: Composition of the studied alloys.

\begin{tabular}{lcc}
\hline Alloy & Zn\% & $\mathrm{Ni} \%$ \\
\hline I & 95.0 & 5.0 \\
II & 90.0 & 10.0 \\
III & 85.0 & 15.0 \\
\hline
\end{tabular}

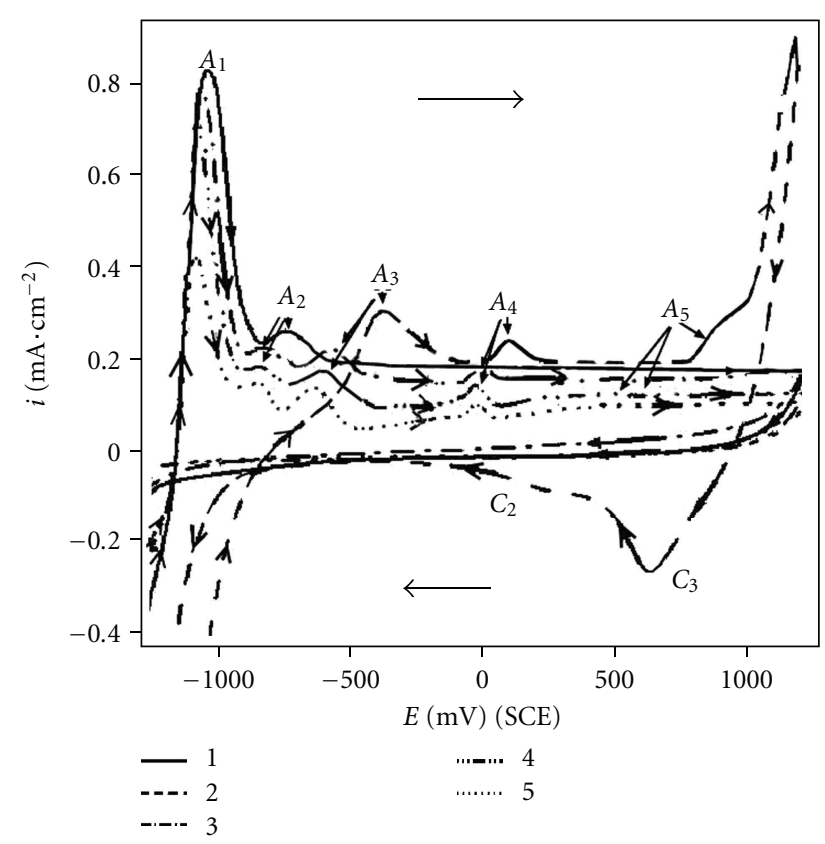

Figure 1: Cyclic voltammograms of (1) Zinc, (2) Nickel, (3) alloy I, (4) alloy II, and (5) alloy III in $0.15 \mathrm{~N}$ of borate buffer solution at $25^{\circ} \mathrm{C}$ and $50 \mathrm{mVs}^{-1}$.

1 represents the voltammetric behavior of pure Zinc. The anodic excursion exhibits two anodic peaks $A_{1}$ and $A_{2}$ in the active region before the onset of passivation. The two anodic peaks are related to the formation of the anodic peak $A_{1}$ that is related to the formation of $\mathrm{Zn}(\mathrm{OH})_{2}$ while the anodic peak $A_{2}$ is related to the formation of $\mathrm{ZnO}$ [2],

$$
\begin{gathered}
\mathrm{Zn}+2 \mathrm{OH}^{-} \longrightarrow \mathrm{Zn}(\mathrm{OH})_{2}+2 \mathrm{e}^{-} \\
\mathrm{Zn}+2 \mathrm{OH}^{-} \longrightarrow \mathrm{ZnO}+\mathrm{H}_{2} \mathrm{O}+2 \mathrm{e}^{-} .
\end{gathered}
$$

Curve 2 represents the cyclic voltammetric behavior of pure nickel in $0.15 \mathrm{~N}$ of borate buffer solution. The forward sweep is characterized by the appearance of three anodic peaks $A_{3}$, $A_{4}$, and $A_{5}$ which are ascribed to the formation of $\mathrm{Ni}(\mathrm{OH})_{2}$, $\mathrm{NiOOH}$ [13], and $\mathrm{Ni}_{2} \mathrm{O}_{3}$ [14], respectively, as shown in (7) and (8), respectively,

$$
\begin{gathered}
\mathrm{Ni}+2 \mathrm{OH}^{-} \longrightarrow \mathrm{Ni}(\mathrm{OH})_{2}+2 \mathrm{e}^{-} \\
\mathrm{Ni}(\mathrm{OH})_{2}+\mathrm{OH}^{-} \longrightarrow \mathrm{NiOOH}+\mathrm{H}_{2} \mathrm{O}+\mathrm{e}^{-} .
\end{gathered}
$$

Visscher and Barendrecht [15] examined the growth of oxide layer on $\mathrm{Ni}$ surface in alkaline solutions using cyclic voltammetry. They found that the first anodic film is a thin 
layer of $\mathrm{NiO} \cdot \mathrm{nH}_{2} \mathrm{O}$ which transfer to $\mathrm{Ni}(\mathrm{OH})_{2}$ on increasing the anodic potential, on the other hand De Souza et al. [16] suggested that the first layer of $\mathrm{NiO}$ is covered after the anodic scan to a thick film of $\beta-\mathrm{Ni}(\mathrm{OH})_{2}$. At potential above a critical value, the $\beta-\mathrm{Ni}(\mathrm{OH})_{2}$ film is converted to $\beta$ $\mathrm{NiOOH}$ [5]. However, on reversal polarization, $\beta-\mathrm{NiOOH}$ is reduced back to $\beta-\mathrm{Ni}(\mathrm{OH})_{2}$. The reduction of $\mathrm{NiOOH}$ to $\mathrm{Ni}(\mathrm{OH})_{2}$ was observed also in carbonate ions [17]. The backward sweep was characterized with the appearance of two cathodic peaks $\mathrm{C}_{2}$ and $\mathrm{C}_{3}$ which are ascribed to the reduction of $\mathrm{NiOOH}$ to $\mathrm{Ni}(\mathrm{OH})_{2}$ and $\mathrm{Ni}_{2} \mathrm{O}_{3}$ to $\mathrm{Ni}(\mathrm{OH})_{2}$.

The cyclic voltammetric behavior of alloys I, II, and III is represented in Figure 1 curves 3, 4, and 5, respectively. On sweeping the potential in the positive direction, the forward sweep is characterized by the appearance of two potential regions separated by the critical potential $E_{\text {crit }}$ : (i) the selective dissolution potential and (ii) the simultaneous dissolution potential region. It seems that the alloys anodic profiles in these regions lay below those of two pure metals as an indication of decreasing the rates of metals dissolution from these alloys with increasing the nickel content. In the subcritical potential region, selective dissolution of the less noble component, zinc, occurs and results in the appearance of the two anodic peaks $A_{1}$ and $A_{2}$. Visual inspection shows that these anodic peaks are related to the formation of $\mathrm{Zn}(\mathrm{OH})_{2}$ and $\mathrm{ZnO}$, respectively. Considering the content of zinc in the alloys, it seems that the processes involved in the appearance of the anodic peaks $A_{1}$ and $A_{2}$, that is, selective dissolution of zinc and formation of $\mathrm{Zn}(\mathrm{OH})_{2}$ and $\mathrm{ZnO}$, are decreased as shown by decreasing the heights of the anodic peaks $A_{1}$ and $A_{2}$ with increasing nickel content in the alloy. The peak potentials of the anodic peaks $A_{1}$ and $A_{2}$ were shifted towards more active, negative values with increasing nickel content in the alloy as an indication of enhancing the dissolution of zinc from the alloy; see, (1) and (2),

$$
\begin{gathered}
\mathrm{Zn}_{x} \mathrm{Ni}_{y}+2 \mathrm{OH}^{-} \longrightarrow \mathrm{Zn}_{x-1} \mathrm{Ni}_{y}+\mathrm{Zn}(\mathrm{OH})_{2}+2 \mathrm{e}^{-} \\
\mathrm{Zn}_{x-1} \mathrm{Ni}_{y}+2 \mathrm{OH}^{-}+\longrightarrow \mathrm{Zn}_{x-2} \mathrm{Ni}_{y}+\mathrm{ZnO}+\mathrm{H}_{2} \mathrm{O}+2 \mathrm{e}^{-}
\end{gathered}
$$

The potential region II was characterized by the appearance of three anodic peaks $A_{3}, A_{4}$, and $A_{5}$. Visual inspection shows that the anodic peaks $A_{3}$ and $A_{4}$ are related to the formation of $\mathrm{Ni}(\mathrm{OH})_{2}$ and $\mathrm{NiOOH}$ [13] and $\mathrm{Ni}_{2} \mathrm{O}_{3}$ [14], respectively,

$$
\begin{gathered}
\mathrm{Zn}_{x-2} \mathrm{Ni}_{y}+2 \mathrm{OH}^{-} \longrightarrow \mathrm{Zn}_{x-2} \mathrm{Ni}_{y-1}+\mathrm{Ni}(\mathrm{OH})_{2}+2 \mathrm{e}^{-} \\
\mathrm{Ni}(\mathrm{OH})_{2}+\mathrm{OH}^{-} \longrightarrow \mathrm{NiOOH}+\mathrm{H}_{2} \mathrm{O}+\mathrm{e}^{-}
\end{gathered}
$$

$\mathrm{X}$-ray diffraction analyses of $\mathrm{Zn}-\mathrm{Ni}$ alloys at potential values noble to the potential region of the anodic peak $A_{2}$ and at potential more noble that of peak $A_{4}$ are shown in Figures 2 and 3 for alloys II and III, respectively. Figure 2 shows the existence of $\mathrm{ZnO}$ and $\mathrm{Zn}(\mathrm{OH})_{2}$ with preferred orientations (101) and (224), respectively, on the surface of alloy II. Also,

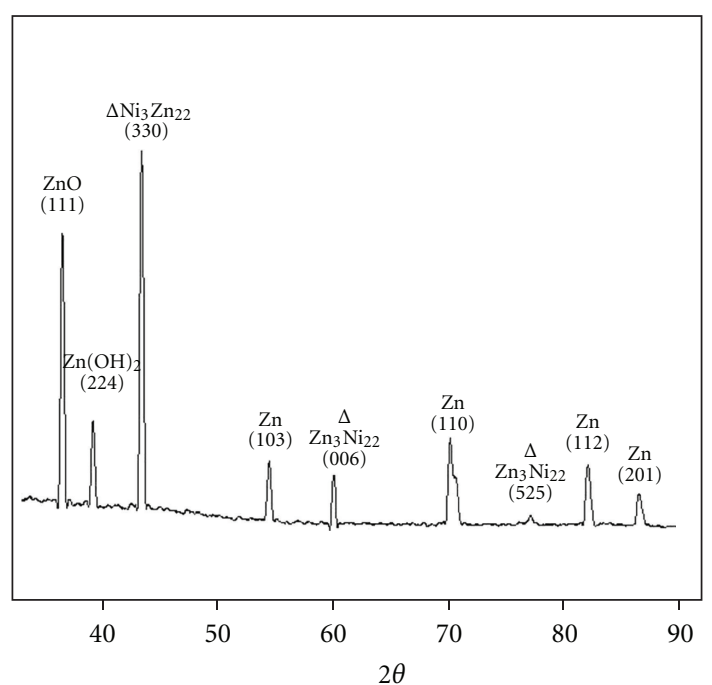

Figure 2: X-ray diffraction pattern of alloy I surface potentiodynamically polarized to $-600 \mathrm{mV}$ at $25^{\circ} \mathrm{C}$ and $50 \mathrm{mVs}^{-1}$.

Figure 3 shows the presence of $\mathrm{Zn}(\mathrm{OH})_{2}, \mathrm{ZnO}, \mathrm{Ni}(\mathrm{OH})_{2}$, and $\mathrm{Ni}_{2} \mathrm{O}_{3}$ with preferred orientations (008), (101), (002), and (202), respectively, on the surface of alloy III. From these results, it appears that the initial stage of the anodic oxidation of $\mathrm{Zn}-\mathrm{Ni}$ alloys involves selective dissolution of less noble metal component (zinc). It seems that $\mathrm{NiOOH}$ is dehydrated later during the movement of the electrode to carry out XRD analysis to $\mathrm{Ni}_{2} \mathrm{O}_{3}$,

$$
2 \mathrm{NiOOH} \longrightarrow \mathrm{Ni}_{2} \mathrm{O}_{3}+\mathrm{H}_{2} \mathrm{O}
$$

The complementary relationship between the anodic and the cathodic peaks was obtained by reversing the potential at different step potentials $E_{s}$ (Figure 4 ). When $E_{s}$ lies between the potential of the anodic peaks $A_{1}$ and $A_{2}$, only the cathodic peak $C_{1}$ appears which is ascribed to the reduction $\mathrm{Zn}^{+2}$ species to $\mathrm{Zn}$. No more cathodic peaks appear on reversing the potential at values noble to the anodic peak $A_{2}$. On reversing the potential at nobler values, the peak current density of the cathodic peak $C_{1}$ was increased, and its peak potential was displaced towards more negative values.

The effect of increasing sweep rate was studied for the three alloys in $0.15 \mathrm{~N}$ of borate buffer solution at $25^{\circ} \mathrm{C}$. Figure 5 represents the cyclic voltammetric behavior of alloy I at different sweep rates. It seems that increasing sweep rate increased the peak potential of all anodic peaks and shifted their potentials in the positive direction. Figure 6 represents the linear dependence of the peak current density of the anodic peaks on the square root of the sweep rate for the alloy I where straight lines passing by the origin are obtained. The linear relations indicate that the processes involved the appearance of these peaks are diffusion-control processes. For a diffusion-controlled process, the peak current $i_{p}\left(A_{x}\right)$ is related to the scan rate by the following equation [18]:

$$
i_{p}=a b z^{1 / 2} c D^{1 / 2} v^{1 / 2}
$$




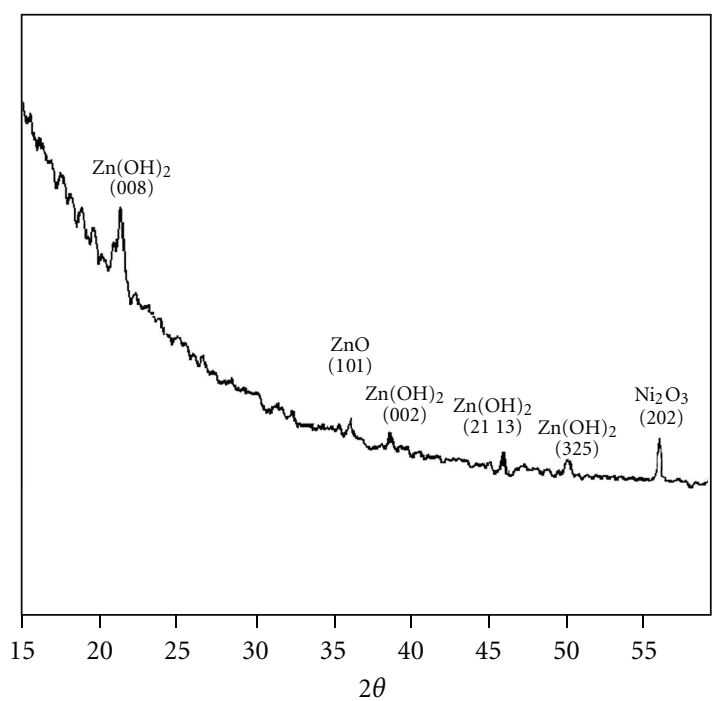

Figure 3: X-ray diffraction pattern of alloy III surface potentiodynamically polarized to $1300 \mathrm{mV}$ with at $25^{\circ} \mathrm{C}$ and $50 \mathrm{mVs}^{-1}$.

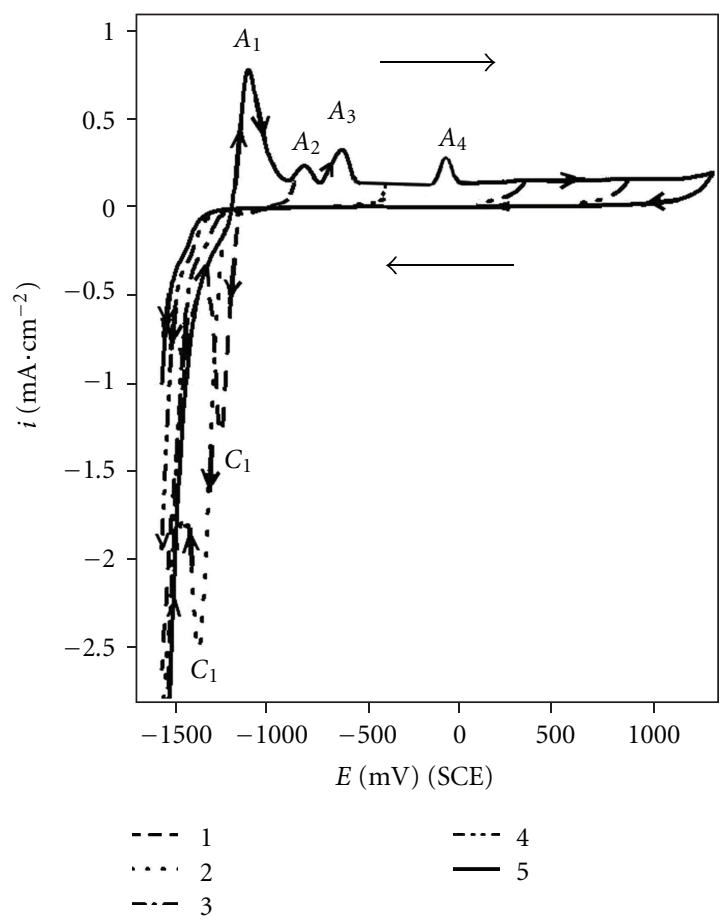

FIGURE 4: Cyclic voltammograms of alloy I in $0.15 \mathrm{~N}$ of borate buffer solution at $25^{\circ} \mathrm{C}$, scan rate $50 \mathrm{mVs}^{-1}$, and various reversing anodic potentials: (1) $-900 \mathrm{mV}$, (2) $-300 \mathrm{mV}$, (3) $350 \mathrm{mV}$, (4) $900 \mathrm{mV}$, and (5) $1300 \mathrm{mV}$.

where $a$ and $b$ are constant, $C$ is concentration of the diffusive species, $D$ is the diffusive coefficient of the diffusing species, and $z$ is the number of the exchanged electrons.

The cyclic voltammetric behavior of $\mathrm{Zn}-\mathrm{Ni}$ alloys at $25^{\circ} \mathrm{C}$ and at scan rate $50 \mathrm{mVs}^{-1}$ was examined in different concentration of borate buffer solution, and the results of alloy I is given in Figure 7. The peak current densities of the anodic peaks were increased, and their corresponding

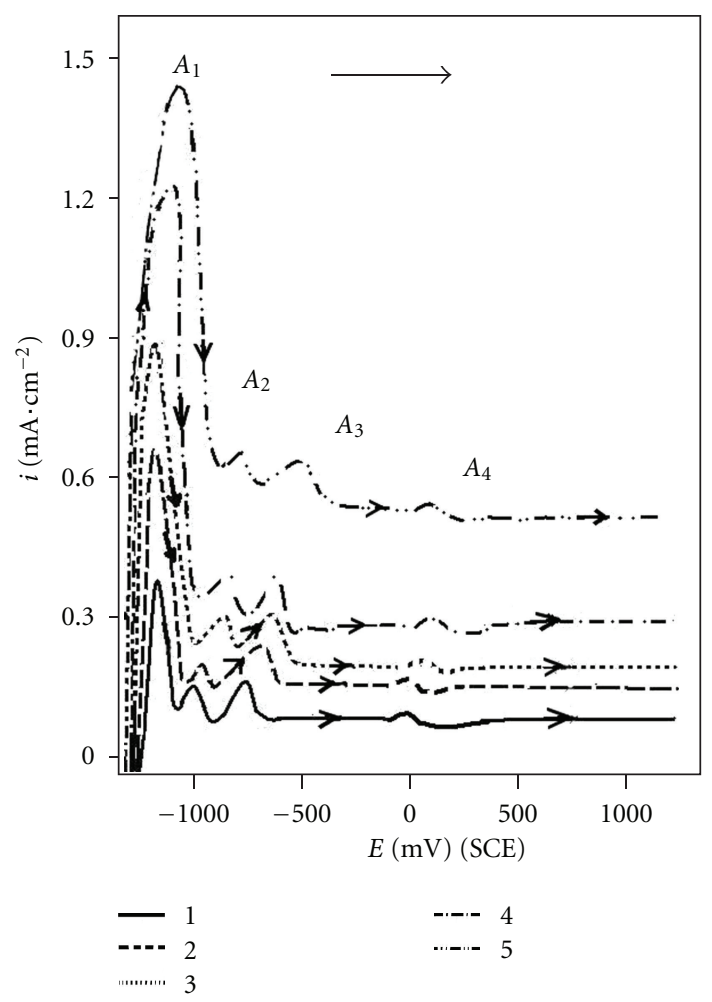

FIGURE 5: Cyclic voltammograms of alloy I in $0.15 \mathrm{~N}$ of borate buffer solution at $25^{\circ} \mathrm{C}$ and various scan rates; (1) $25 \mathrm{mVs}^{-1}$, (2) $50 \mathrm{mVs}^{-1}$, (3) $100 \mathrm{mVs}^{-1}$, (4) $125 \mathrm{mVs}^{-1}$, and (5) $150 \mathrm{mVs}^{-1}$.

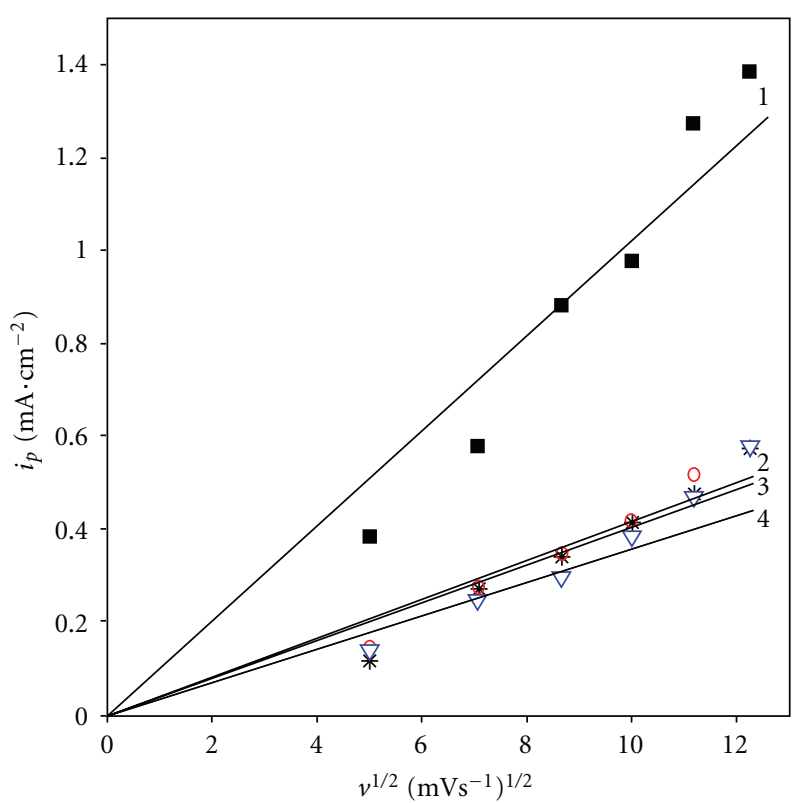

Figure 6: Relation between the peak current density, $i_{p}$, and the root of scan rate for the anodic peaks for alloy I in Borate buffer solution: (1) $A_{1}$, (2) $A_{2}$, (3) $A_{3}$, and (4) $A_{4}$.

potentials are shifted towards more negative values with increasing the borate buffer solution concentration. Figure 8 


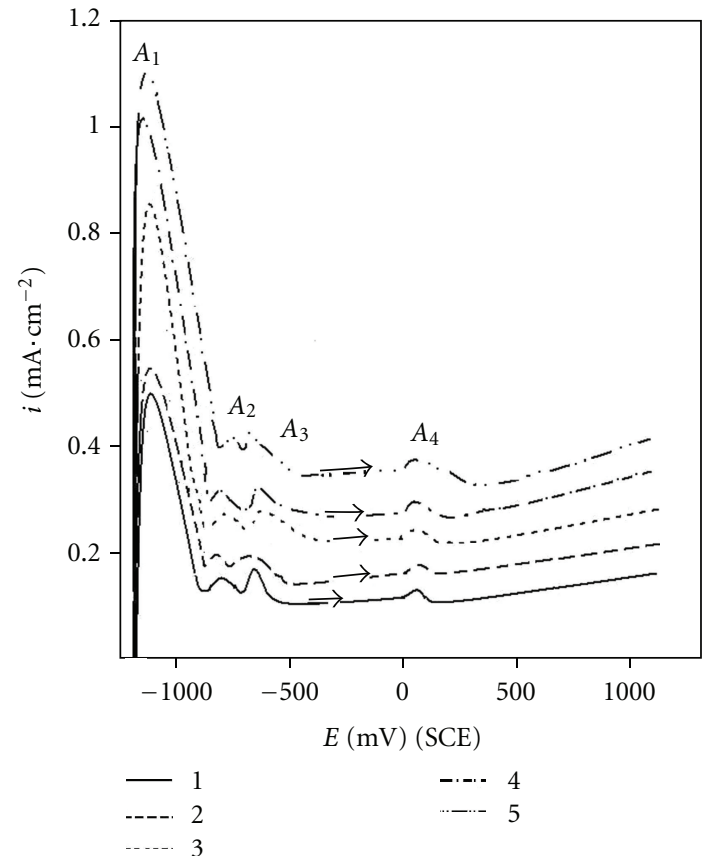

Figure 7: Cyclic voltammograms of alloy I at $25^{\circ} \mathrm{C}$ scan rate $50 \mathrm{mVs}^{-1}$ and in various concentrations of borate buffer solutions; (1) $0.1 \mathrm{~N},(2) 0.15 \mathrm{~N},(3) 0.2 \mathrm{~N}$ (4) $0.25 \mathrm{~N}$ and (5) $0.4 \mathrm{~N}$.

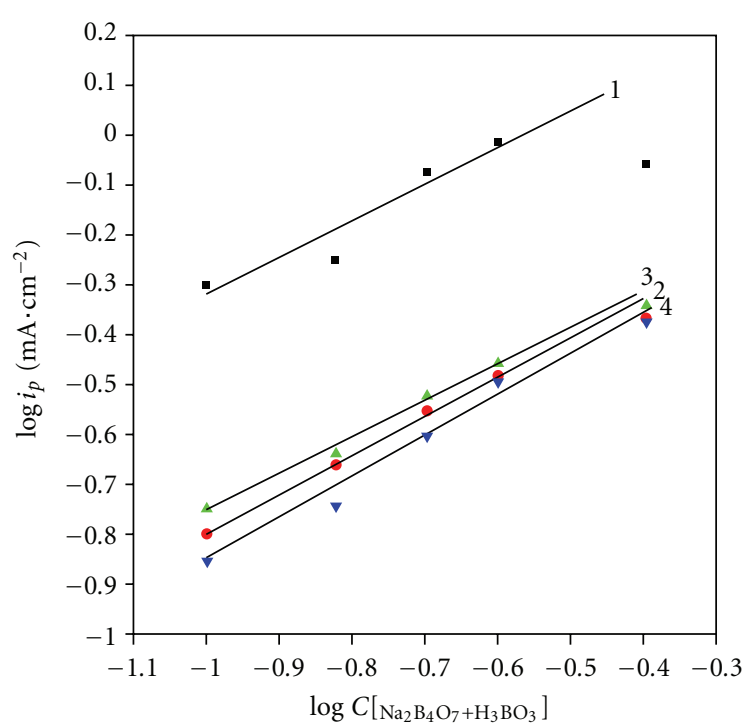

FIGURE 8: Relation between the peak current density of the anodic peaks, $i_{p}$, and $\log C_{\left[\mathrm{H}_{3} \mathrm{BO}_{3}+\mathrm{Na}_{2} \mathrm{~B}_{4} \mathrm{O}_{7}\right]}$ for alloy I; (1) $A_{1}$, (2) $A_{2}$, (3) $A_{3}$ and (4) $A_{4}$.

represents the linear relationship between $\log C_{\mathrm{Na}_{2} \mathrm{~B}_{4} \mathrm{O}_{7}}$ and $\log i_{p}$ of the anodic peaks of the alloy I.

In order to get more information about the electrochemical behavior of $\mathrm{Zn}-\mathrm{Ni}$ alloys in borate buffer solution, potentiostatic current/time were performed at different anodic steps $E_{s}$. Figure 9 shows the current transients for alloy I in $0.15 \mathrm{~N}$ of borate buffer solution at $25^{\circ} \mathrm{C}$. It seems that the current time transient densities decrease monotonically with time to reach a steady state value. The more positive

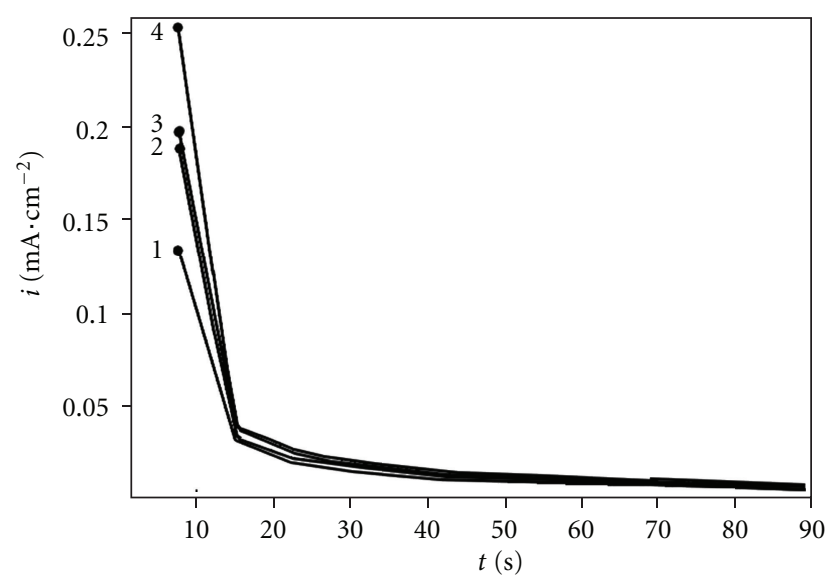

Figure 9: Current transients versus time recorded for alloy I in $0.15 \mathrm{~N}$ of Borate buffer solution at $25^{\circ} \mathrm{C}$ and constant anodic step potentials; (1) $-900 \mathrm{mV}$, (2) $-600 \mathrm{mV}$, (3) $200 \mathrm{mV}$ and (4) $1000 \mathrm{mV}$.

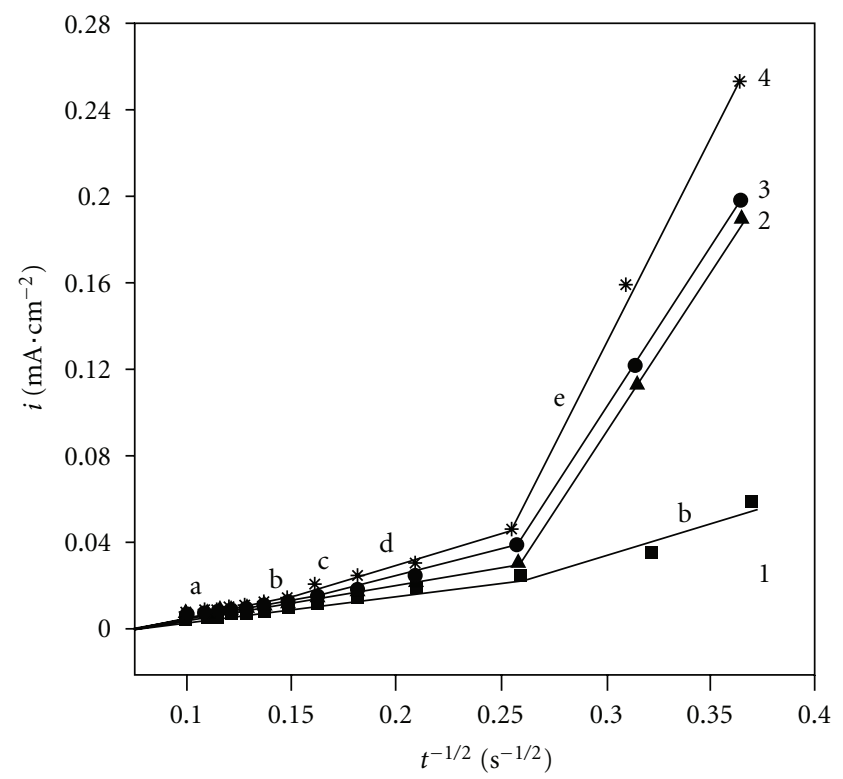

Figure 10: Dependence of the current density on $t^{-1 / 2}$ for the descending portions of the current transients for alloy I in $0.15 \mathrm{~N}$ of Borate buffer solution at $25^{\circ} \mathrm{C}$ : (1) $-900 \mathrm{mV},(2)-600 \mathrm{mV}$, (3) $200 \mathrm{mV}$, and (4) $1000 \mathrm{mV}$.

potential, the steady current, increases as an indication of increasing in the thickness of anodically formed layer. The continuously decreasing parts of the current transients fit linear $i$ versus $t^{-1 / 2}$ relationships, Figure 10, going through the origin and showing interesting features. When $E_{s}=$ $-900 \mathrm{mV}$, the plot consists of two portions with each one obeyed a linear relationship, which represent the formation of two layers. These layers are $\mathrm{Zn}(\mathrm{OH})_{2}, \mathrm{ZnO}$. When $E_{s}=$ $-600 \mathrm{mV}$, the plot consists of three portions with each one obeyed a linear relationship, which represent the formation of two layers. These layers are $\mathrm{Zn}(\mathrm{OH})_{2}, \mathrm{ZnO}$, and $\mathrm{Ni}(\mathrm{OH})_{2}$. If $E_{s}$ at $200 \mathrm{mV}$, the data represent a plot consisting of four portions as a result of the formation of four layers, which 
are $\mathrm{Zn}(\mathrm{OH})_{2}, \mathrm{ZnO}, \mathrm{Ni}(\mathrm{OH})_{2}$, and $\mathrm{NiOOH}$. Similarly, if $E_{s}$ is held at $1000 \mathrm{mV}$, the data represent plots consisting of five portions as an indication of the four layers. The fifth layer is probably $\mathrm{Ni}_{2} \mathrm{O}_{3}$. The formation of these five layers involves a nucleation and growth mechanism under diffusion control.

\section{Conclusions}

(1) The cyclic voltammetric behavior of zinc-nickel alloys was studied in $0.15 \mathrm{~N}$ of borate buffer solution using cyclic voltammetry, anodic polarization, and current time/transient techniques.

(2) The anodic voltammetric profiles of the alloys lie below those of the pure metals indicating decreased rates of dissolution of the two metals, zinc and nickel, from the alloys. On alloying with nickel, the rate of zinc dissolution was decreased which increases its protective life as sacrificial anode for protecting automobile body against corrosion.

(3) The forward sweep was characterized by the appearance of five anodic peaks corresponding to the formation of $\mathrm{Zn}(\mathrm{OH})_{2}, \mathrm{ZnO}, \mathrm{Ni}(\mathrm{OH})_{2}, \mathrm{NiOOH}$, and $\mathrm{Ni}_{2} \mathrm{O}_{3}$ before oxygen evolution takes place.

(4) The backward sweep shows two cathodic peaks in pure nickel corresponding to the reduction of $\mathrm{Ni}_{2} \mathrm{O}_{3}$ and $\mathrm{NiOOH}$ to $\mathrm{Ni}(\mathrm{OH})_{2}$, the backward sweep in alloys shows only one cathodic peak due to the reduction of $\mathrm{Zn}^{+2}$ species to $\mathrm{Zn}$.

(5) A study of the effect of scan rate has shown that the dissolution processes in the regions of the anodic peaks in the alloys are under diffusion control.

(6) Potentiostatic current/time transient measurements reveal that the formation of $\mathrm{Zn}(\mathrm{OH})_{2}, \mathrm{ZnO}$, $\mathrm{Ni}(\mathrm{OH})_{2}, \mathrm{NiOOH}$, and $\mathrm{Ni}_{2} \mathrm{O}_{3}$ layers involves a nucleation and growth mechanism under diffusion control.

\section{References}

[1] E. E. Abd El Aal, "Effect of $\mathrm{Cl}^{-}$anions on zinc passivity in borate solution," Corrosion Science, vol. 42, no. 1, pp. 1-16, 2000.

[2] M. C. H. McKubre and D. D. Macdonald, "Dissolution and passivation of zinc in concentrated aqueous hydroxid," Journal of the Electrochemical Society, vol. 128, no. 3, pp. 524-530, 1981.

[3] X. Shan, D. Ren, P. Scholl, and G. Prentice, "Coulometric and ellipsometric measurements of passive film thickness on zinc electrodes in $\mathrm{KOH}$ solution," Journal of the Electrochemical Society, vol. 136, no. 12, pp. 3594-3598, 1989.

[4] S. S. Abd El Rehim, E. E. Fouad, S. M. Abd El Wahab, and H. H. Hassan, "The influence of some sulphur-containing anions on the anodic behaviour of zinc in an alkaline medium," Journal of Electroanalytical Chemistry, vol. 401, no. 1-2, pp. 113-118, 1996.

[5] S. B. Saidman, J. R. Vilche, and A. J. Arvia, "Voltammetric response of zinc in sodium hydroxide solutions containing sodium sulphide," Electrochimica Acta, vol. 39, no. 10, pp. 1401-1407, 1994.

[6] R. W. Powers and M. W. Breiter, "Anodic dissolution and passivation of zinc in concentrated potassium hydroxide solutions," Journal of the Electrochemical Society, vol. 116, no. 6, pp. 719-729, 1969.

[7] S. S. Abd El Rehim, E. E. Fouad, S. M. Abd El Wahab, and H. H. Hassan, "Passivity and passivity breakdown of zinc anode in alkaline medium," Werkstoffe und Korrosion, vol. 46, no. 11, pp. 633-638, 1995.

[8] A. C. Makrides, "Electrochemistry of Surface Oxides," Journal of the Electrochemical Society, vol. 113, p. 1158, 1966.

[9] R. J. Smith, R. E. Hummel, and J. R. Ambrose, "The passivation of nickel in aqueous solutions-II. An in situ investigation of the passivation of nickel using optical and electrochemical techniques," Corrosion Science, vol. 27, no. 8, pp. 815-826, 1987.

[10] J. F. Wolf, L.-S. R. Yeh, and A. Damjanovic, "Anodic oxide films at nickel electrodes in alkaline solutions-II. pH dependence and rate determining step," Electrochimica Acta, vol. 26, no. 7, pp. 811-817, 1981.

[11] E. E. Abd El Aal, "Breakdown of passive film on nickel in borate solutions containing halide anions," Corrosion Science, vol. 45, no. 4, pp. 759-775, 2003.

[12] M. A. Hopper and J. L. Ord, "Optical study of the growth and ox? Dation of nickel hydroxide films," Journal of the Electrochemical Society, vol. 120, no. 2, pp. 183-186, 1973.

[13] R. W. Power, "Anodic dissolution and passivation of zinc in concentrated potassium hydroxide solutions," Journal of the Electrochemical Society, vol. 116, no. 6, pp. 719-729, 1969.

[14] F. Zucchi, M. Fonsati, and G. Trabanelli, "Corrosion and corrosion inhibition of nickel in $\mathrm{HClO}$ solutions using the EQCM technique," Journal of Applied Electrochemistry, vol. 28, no. 4, pp. 441-447, 1998.

[15] W. Visscher and E. Barendrecht, "Anodic oxide films of nickel in alkaline electrolyte," Surface Science, vol. 135, no. 1-3, pp. 436-452, 1983.

[16] L. M. M. De Souza, F. P. Kong, F. R. McLarnon, and R. H. Muller, "Spectroscopic ellipsometry study of nickel oxidation in alkaline solution," Electrochimica Acta, vol. 42, no. 8, pp. 1253-1267, 1997.

[17] J. L. Weininger and M. W. Breiter, "Cyclic Voltammetry of Nickel-Metal Electrode in KOH," Journal of the Electrochemical Society, vol. 111, p. 707, 1964.

[18] P. Delhay, New Instrumental Methods in Electrochemistry, John Wiley \& Sons, New York, NY, USA, 1954. 

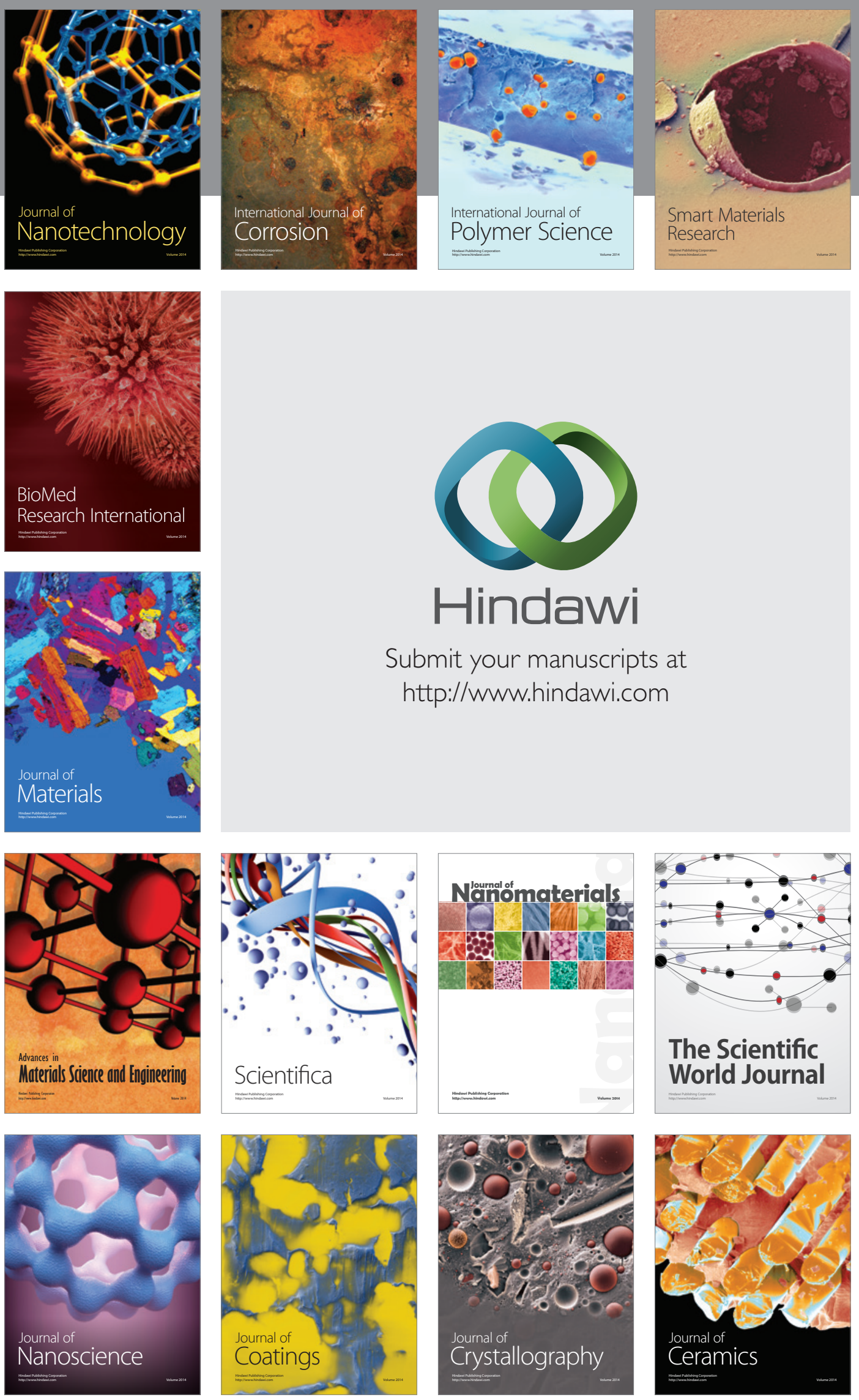

The Scientific World Journal

Submit your manuscripts at

http://www.hindawi.com

\section{World Journal}

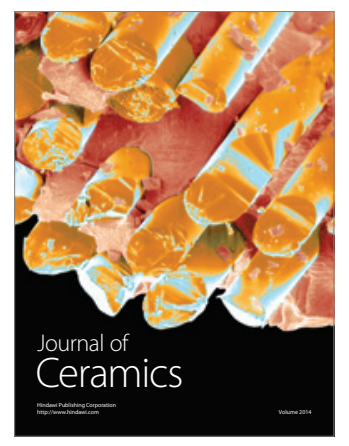

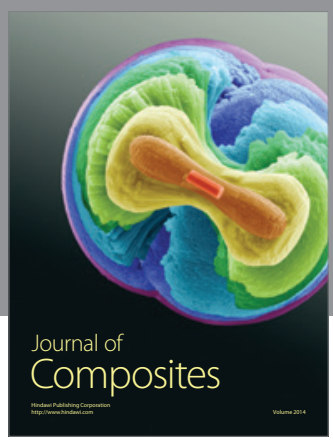
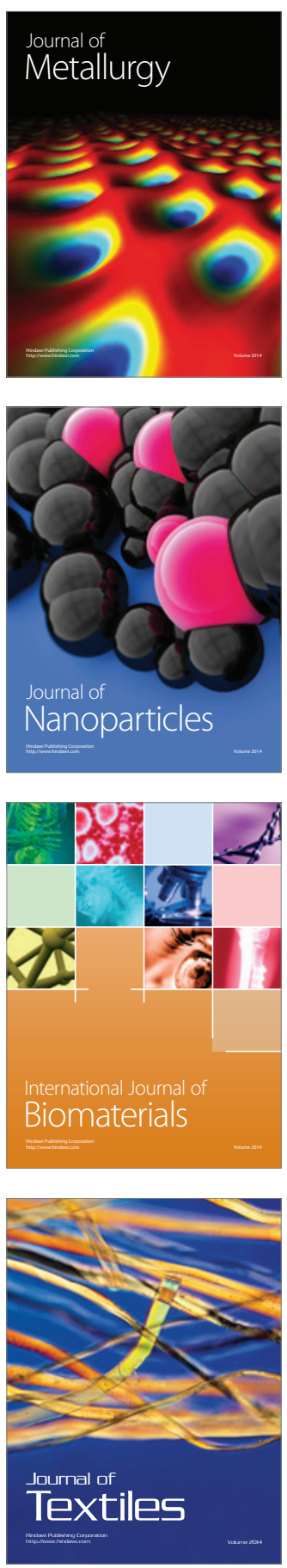